Iryna I. Koval, Master Student, Postgraduate Student at the Department of Ecological Safety and Nature Protection Activity of V. Chornovil Institute for Sustainable Development ORCID ID 0000-0001-8154-4154 e-mail: iralito@i.ua

Volodymyr D. Pohrebennyk, Full professor, D. S., Professor at the Department of Ecological Safety and Nature Protection Activity of V. Chornovil Institute for Sustainable Development

ORCID ID 0000-0002-1491-2356e-mail: vpohreb@gmail.com

Lviv Polytechnic National University, Lviv, Ukraine

\title{
APPROACHES TO BUILDING INTEGRATED SYSTEM OF MUNICIPAL SOLID WASTE MANAGEMENT: CLASSIFICATION OF PACKAGING WASTE
}

\begin{abstract}
In the article the problem concerning packaging waste management was treated, examples of enhanced practice achievement worldwide as to its handling were presented. Key peculiarities of packaging wastes were studied and their classification was developed. Several options for substitute of packaging for particular kinds of goods were suggested.
\end{abstract}

Keywords: packaging waste $(P W)$; classification; packaging materials (PM); recycling; biopackaging

\section{Introduction}

Ukraine ranks number one in rubbish amount per capita globally since 2012. Total volumes of waste that accumulated throughout the independence years in our country, according to different estimations, amounts to 30 milliard tons. According to the information of State Statistical Service, in 2016 in Ukraine approximately 300 million tons of waste was generated, of which 620,000 tons are hazardous [1].

Ukraine as a state can earn on rubbish, indeed. It could have saved 2,200 million $\mathrm{m}^{3}$ of natural gas, 634 million kilowatt-hour of electric power and besides, obtain approximately 1,8 million tons of raw materials, which can be used for manufacturing of packagings, containers, construction materials and other needs. Also, apart from economic benefits, we will have social benefit by creating 50 thousand jobs and, which is really essential, environmental advantage - for instead of 6148 current landfills and 32984 unauthorized ones we will obtain certain defined number of authorized centres for handling municipal solid waste (MSW) almost 300 units. On average, to build and activate a single one object like that, which will be able to reprocess up to 300,000 tons of MSW a year, it will take three years and 70 million dollars' investments. Just throughout this year almost two tens of foreign investors showed wish to deal with waste recycling here.

According to the data of Minregionbud in Ukraine, more than 11-12 million tons of MSW is generated yearly [2], including significant part of already used packaging materials (PM) - about 25-40\% [3].

CC I.I. Koval, V.D. Pohrebennyk, 2018 
Today consumer packaging became essential part of contemporary life. Now we perceive it as a material attracting us with its appearance and as a protective material which secures product's quality. At the same time, PW became main contaminant of the environment $[3,4]$.

In [5] data on averaged composition of MSW in Ukraine presented: materials containing cellulose (paper, cardboard, newspapers, wrappers and other packaging materials (PM) $)-30-35 \%$; foodstuff waste $-28-30 \%$; metals $-4 \%$; plastics $-4 \%$; wood $-3 \%$; textile $-5 \%$; glass, ceramics $-7 \%$; other $-10-12 \%$. So, PW makes up considerable rate of total MSW volume. However, in the above mentioned list PM are absent, in particular polymers, which today are widely used. Consequently, there is high probability that volume of PW is significantly greater, though today it is not possible to find it out clearly, as long as reliable calculation of such waste is not conducted in the state. In Ukraine there is no official classification of PW either, which could be effectively applied in practice of separate collection and in technology process.

Present day's global trends are enhancement of up-to-date and high quality PM, applying of scientific and technologic achievements for enhancing their properties. It will enable not only to reduce their weight, but also to create multiuse packaging.

To implement such practices in Ukraine, it is first necessary to initiate culture of PW handling at countrywide level. So, if rate of aware population increases to sort it purposefully, amount of raw materials for further recycling will also increase, which will facilitate the process of the following stages of integrated system in municipal solid waste management.

For better choice of efficient PW handling and appropriate methods of its recycling and disposal it is necessary to classify them.

The aim of the work is building PW classification for enhancement in integrated MSW management.

\section{Analysis of recent studies and publications}

For developing and introducing integrated system of MSW management in Ukraine, it is required to work out and put into effect appropriate legislation drafts, standards, regulatory acts, legislative regulations, clear waste classifier and their compliance in practice. Issue of enhancement in MSW classification presented in works by T.A. Safranov [6], T.M. Dovga [7], S.O. Nikanorov [8], T.F. Zhukovs'ky [9], etc. They researched and worked out each own MSW classification, based on studied experience of EU countries as to its management. Nevertheless, these studies and elaborations are not sufficient for building integrated system of MSW management. Therefore, to achieve the goal, grouping of PW should be done.

\section{Materials and methods of research}

Work methods are based on analysis of principles in waste groups management, by using method of convergence from general toward local and interrelations between quantitative and qualitative characteristics. During carrying out the work, data published both by home and foreign authors were used, as well as materials of author's own research dedicated to complex problems in MSW management. 


\section{Presentation of material}

Today global manufacturing PM reaches 1 milliard 350 million tons, including paper and cardboard -500 million tons, polymers -300 million tons, glass -40 million tons, metal - 150 million tons, most of which to be recycled. Consuming of packaging per capita is astounding, for example, in European countries PW makes up 100-170 kg per person a year, in the USA - 230-280 kg per capita a year, in Japan $-400 \mathrm{~kg}$ and it tends to grow $[10,11]$.

As for kinds of packaging, recently gain in demand for them yearly amounts to as follows: 1,5-3\% for foodstuff packaging; 4,5-5\% for household appliances, 2,5-3\% for cosmetics and pharmaceutical products and 1-1,5\% for other products.

In Ukraine considerable part of MSW volume is placed by PW, at that, persistent trend towards their increasing is observed [10].

As author mentioned [12], discarded MSW means wasted material and energy resources.

Unfortunately, the problem of PW handling, which are the most beneficial as recycled materials within MSW, is essential link in general issue of handling all MSW. Apparently this happened through lack of special law on packaging and its waste in Ukraine. It almost caused impossibility to create efficient system of handling waste like the ones that have successfully been working for a long time already in many European countries based on European law - Directive 94/62/EC [13].

The problem mentioned is complex and it requires framing of both organizational conditions at countrywide level (building of modern system in PW handling, adapted to standards and regulations of European Directive 94/62/EC «On Packaging and Packaging Waste» with taking into account Ukrainian realia and mentality) and also solving particular technical challenges as to collection, sorting and recycling of PW. Direction of these activities is dictated by necessity for their usage as recycled materials [12].

To frame efficient integrated system of MSW management, essential moment is proper classifying parts of used elements of product which exhausted its main function. Therefore, such classification of PW is suggested by us (Fig. 1). By sources of generation: manufacturers/suppliers; consumers. By purpose: (A-1) inner packaging/container (preservation packaging). They comprise: wrapping paper, cardboard boxes, bags, bottles (jars), lids, etc.; (A-2) accessory packaging material - labels, tapes, cushioning, inserting liners, wood wool, paper wrappers, packthread and so on; (A-3) outer packaging (transportation container/packaging). Varieties of such one are: wooden solid and grid/lattice crates, metal and plastic boxes, barrels, containers, bags, pallets, as well as corrugated cardboard boxes. By lifecycle: throwaway and multiuse. By sizes: small-sized and large-sized. By materials of products: wood, paper, cardboard, textile, metal, glass, polymers, mixed materials.

One of essential materials for making packaging is wood. It plays important role in production of transportation packaging for hauling of large-sized cargo and fragile items in any sizes, which require rigid and strong packaging. Now it is rather used to make packaging for costly goods: barrels, tubes and craft boxes for collection wines, baskets, various gift accessories, etc. Wooden PM means environmentallyfriendly packed product and is evidence of its high quality.

The most widespread PM not only in our country, but also abroad are cardboard and paper. Various paper bags and packs are made for products of food, light, pharmaceutical, perfume and cosmetic industries, etc. 
By normative documents, basic kinds of consumers packaging from cardboard and paper are as follows: cardboard box, pack and bag. Paper bags can be with polyethylene coating.

Textile PM - burlap linen, jute-linen, jute bags, etc. They are used for loose materials - sugar, starch, flour and so on. These bags may contain polyethylene coating.

Metal packaging takes rather large-scale segment of materials market in Ukraine.

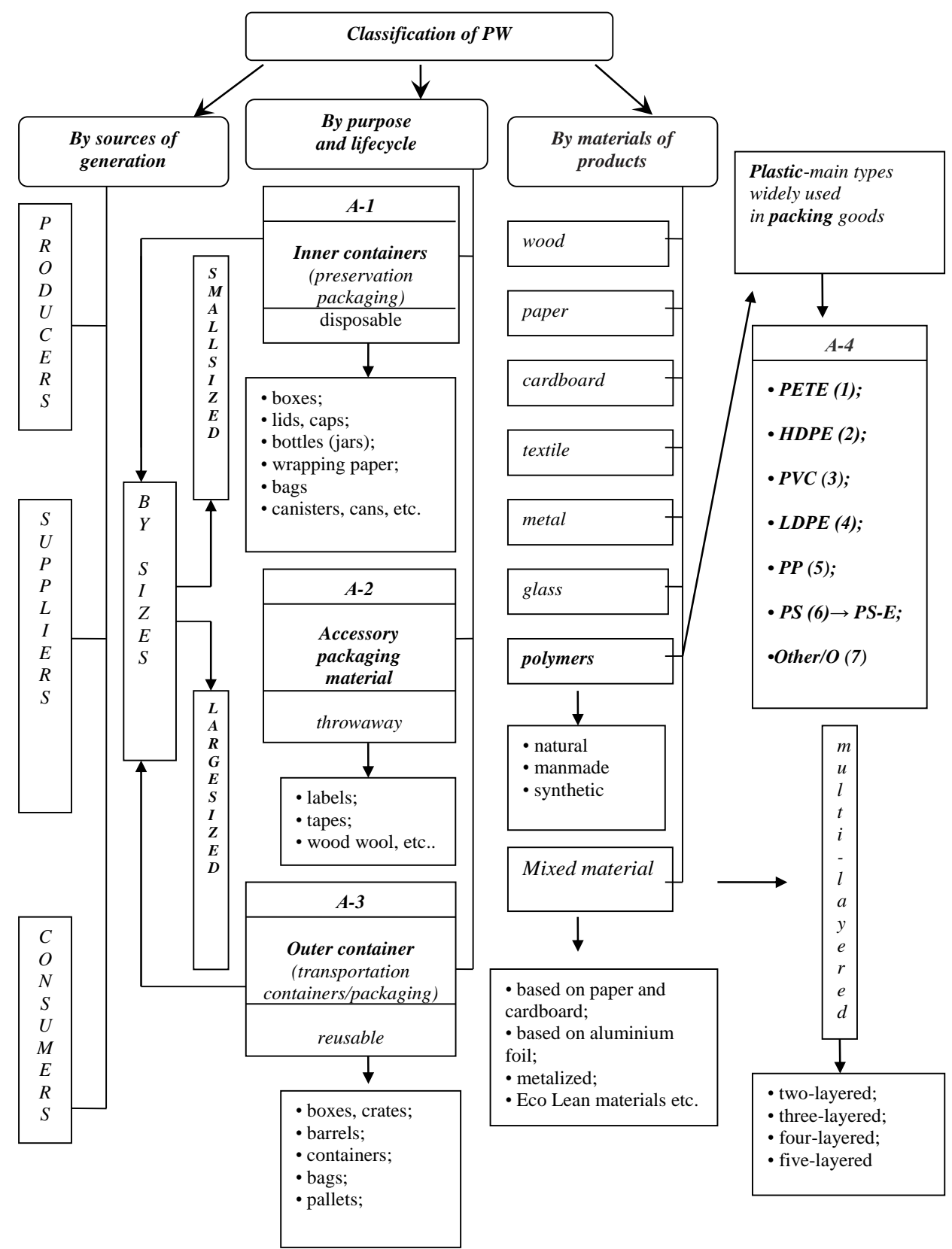

Fig. 1 - Classification of PW 
Such materials are extensively used in beverages, preserved foods and chemical industries. In compliance with normative documents, they comprise as follows: steel and aluminium containers and jars, aluminium spray cans and tubes. Those ones are considered to be the most widespread used packaging and one of the most costeffective for manufacturers [4].

One of the most traditional materials used for packaging is glass. It is considered to be the safest for health as a food PM. It is widely used in such industries as food, perfumed and cosmetic, chemical and pharmaceutical. In supervisory authority for foods (FDA) in the USA, glass possesses special status: it is the only foodstuff PM to gain qualification level "Basically Safe". And generally, product packed in glass material is perceived as a high quality product [4].

PM from polymers gained widespread use. Broad list of products belong to them: 1) PET-bottles, jars, boxes (polyethylene terephthalate /PET/PETE) - for cooled foods and drinks, milk, mineral water, fruit juices, seasonings, cosmetics, cleaners, detergents; 2) semi-rigid packaging from HDPE (high density polyethylene /HDPE), including bottles from dairy products, juices and waters, flasks from shampoo, shower gel, bleachers, cleaners and detergents, containers for foods, disposable dishware, grocery packaging bags, rubbish bags; 3) PM from PVC (polyvinyl chloride PVC) are used in food industry, for example for loose products, for bottling vegetable oils. Also such type of material is applied in chemical industry for production of containers for loose food products. Windows, films for foodstuff, stretched ceilings, toys, pipework, jalousies and containers for process liquids are produced from this material as well; 4) PM from LDPE (low density polyethylene/LDPE). Most of bags, rubbish bags, pliable containers, films for food products, bottles for water and cleaners/detergents and so on belong to this kind; 5) polymeric packaging from PP (polypropylene/PP). This type of material is used for yoghurts, syrups, ketchups. Containers for food products and their freezing as well as reusable dishware, disposable dishware for hot meals, baby bottles, caps are made from this plastic; 6) plastic material from PS (polystyrene/PS) is used in production of cups for coffee, yoghurts, containers for fast food, eggs, vegetables, fruit, meat, fish. Disposable tableware, audiotapes and cases for CD are made from this material, too; 7) plastic material, which contains polycarbonate $(P C)$ or polyamide $(P A)$ or other compositions $(O T H E R / O)$ is applied in production of baby polycarbonate bottles, reusable bottles for water, containers for storage of food products, etc.

By methods of obtaining, polymers can fall into: 1) synthetic, natural (biopolymers), modified (manmade). The former ones are obtained by synthesis of low-molecular compounds, in particular polyethylene - product of oil processing (petrochemicals), and bio-polyethylene. Biopolymers are derived from natural materials, for example, natural rubber (caoutchouc), proteins, nucleic acids (DNA, RNA), pectin substances, polysaccharides - cellulose, starch, etc.). Modified polymers are derived by way of physical or chemical modification of natural polymers (for example, viscose and acetated fibers from cellulose) or of synthetic polymers. Manmade polymers, produced worldwide, comprise: polyethylene (LDPE, HDPE), polypropylene (PP), polyvinyl chloride (PVC), polystyrene (PS), polyurethane (PUR) and polyethylene terephthalate (PET). Mixed packaging - is created during combination of different materials in the manufacturing process. For example: coating of cardboard, paper, foil, fabric or Eco Lean material by film from melted polymer, resulted in obtaining strong and colorful PM. 
Today approximately 150 kinds of plastics are produced. Blends of various polymers make up $30 \%$ of them. Regular thermoplastics - HDPE, LDPE, PP, PS, PVC make up to $80 \%$ of polymers ever produced. Engineering plastics polycarbonates, polyamides, PET, polyphenylene oxide - accounts for up to $19 \%$. Remaining $1 \%$ are polymers with specific, unique properties: polyester-ketones, polyphenylene sulfides and many other [14].

By level of recycling complication, plastic waste falls into three basic groups: 1) polymers with good properties. Such wastes are clean, sorted and easily recyclable. During processing, using up to $90 \%$ of materials like that is possible; 2) polymers with medium properties. This group comprises wastes, which contain certain amount of contaminants and require sorting. Recycling of these wastes is related with additional expenses for separation, washing, etc. 20-30\% of such raw material's initial amount comes to processing; 3) hardly recyclable polymers. Those are, first of all, badly contaminated and mixed wastes. Their processing in most cases is not cost-effective.

It is worth mentioning that basic raw material for polymer-making is crude oil and petrochemicals. Therefore, applying of plastic waste to obtain recycled raw material is reasonable. Advantages of this methods are saving of fuel and energy resources as well as natural (virgin) raw materials; reducing level of environmental pollution by waste from consuming and production; new jobs creation; gaining profits by recyclers and economy for purchasers of recyclates, obtained from waste [15].

Recycling envisages using of polymeric waste as basic or auxiliary raw material for issuing new products, i.e. recovered material resources. It is known that price of recycled polymeric raw materials ranges from 2 to $19 \mathrm{UAH} / \mathrm{kg}$, which is 1,5-4 times off the price for virgin raw material.

Amount of biological polymers obtained from recovered raw material accounts for only $1 \%$ of all polymers market. Plant raw material is essential alternative for petroleum, which deposits are constantly depleting. Biologic polymers obtained at present, are based on wood components and annual plants, which contain starch (potato, maize, wheat, rice) and cellulose. Biopackaging contains natural ingredients or additives, which make fast decomposition of polyethylene and at the same time maintain all conveniences which consumers got used to. Furthermore, it is environmentally-friendly. It is costlier than regular plastic one, and can be used for middle-income price segment. Though it will become more affordable in time [16]. So, they can be obtained with the help of some bacteria, fungi and seaweeds, too. In particular, company EPI Environmental Technologies Inc. (EPI Group), Vancouver (Canada), owns basically all researches in the sphere of biodegradable plastic. By co-working with worldwide renowned scientists in this sphere it produces TDPA additives (oxo-biodegradable additives). Such additives bio-decompose regular polymers. It is essential to note that presence of the additive does not change properties of basic polymer at all and, correspondingly, of ready product. Packaging made by applying the additive, will be same strong, well colored and transparent.

The process of biodegrading is two-stage: at the first stage plastic decomposes by oxidization of additives under the heat effect as well as on exposure to ultraviolet solar radiation; at the second stage it biodegrades under the influence of microorganisms in natural conditions [17].

In Great Britain biodegradable PM are made (from maize, starch, rice grain husks, fibres). On packaging from starch colored print can be put, the material is able to be 
heat sealed, food may be put into microwave oven in it. So, today exactly this is the essential signal for producers of PM.

Some countries under the pressure of community environmental organizations pass legislative acts to impose ban or limitation on using some kinds of packaging (for example, polymeric bags, yearly produced about 5 trillion items globally). It concerns Australia, Italy, France and some other countries. For example, in Kenya ban on using polyethylene bags entered into force. This means that anyone who sells, produces or uses such bags will face either 38,000 dollars fine or up to four years' imprisonment. Therefore, substitution of polyethylene bags and packagings of various polymer types for their alternatives is essential. So, we suggest several options for replacement PM of certain kinds of goods which we often come across at a supermarket, as shown in the Table.

Table - Offers as to substitute of packaging for particular kinds of goods

\begin{tabular}{|l|l|l|}
\hline Items of goods & Material & Alternative \\
\hline Potato & Plastic string/net bag & Textile string bag (avoska) \\
\hline Sour cream & Plastic cup, bowl & Glass jar \\
\hline Various grains and flour & Plastic bag & Textile bag \\
\hline $\begin{array}{l}\text { Washing detergent } \\
\text { (powder) «Persil» }\end{array}$ & $\begin{array}{l}\text { Plastic made from recycled } \\
\text { plastic material }\end{array}$ & Paper bag \\
\hline
\end{tabular}

Certainly, PW can be reprocessed either by manufacturers themselves or by recycling enterprise. Those domestic enterprises that made this packaging, have to provide collection and disposal of PW or pay for such service in compliance with tariffs. The rest enterprises which use PW are not to pay tariffs for disposal. Such approach is reasonable: if an enterprise earns profits on packagings, it should guarantee their collection and disposal. For example, a shop applies polyethylene bags in packaging wares for sale. Collection and disposal of these bags should be provided not by a shop but by an enterprise making them, so it has to pay tariffs [18].

In any particular case anyway, this or that kind of packaging should be estimated comprehensively on all the way of its production from raw material to its recovered usage. It is also worth mentioning that any PW, if collected, sorted, prepared (cleaned), can be returned back again to production cycle for making new PM (cullet, wastepaper, aluminium, tinplate) or as recyclates (polymers, mixed materials) for making various products [3].

Association of PM manufacturers together with product makers can play certain role in solving problems of packaging industry in Ukraine. It should control norms of making and packing products, introduce new standards and monitor fulfillment of all accepted rules among manufacturers, which is beneficial to a consumer. Therefore, it is necessary to use global experience in PW management, disposal and recycling [19].

\section{Conclusions}

Peculiarities of PW management both in Ukraine and in European countries are presented. For building effective integrated system of MSW management, PW classification is offered, which will enable to summarize information on packaging. It was found out that the biggest constituent of rubbish waste is packaging. And as 
long as PM environmental problems are associated with their excessive volume and improper quality, it is required to guarantee minimization of used material amount and quantity of material kinds. Furthermore, it is necessary to apply recyclable/reusable materials. It is needed in Ukraine to impose stringent both administrative and material responsibility for environmental pollution; to create organization, independent on particular enterprise structures, for solving environmental pollution problems caused by PW. Significant investment work concerning technical re-equipment of housing and communal services in Ukraine is essential, too. Also high educational (promotional) activity should be carried out, as well as coloured containers for separate rubbish collection by population, on-site stations accepting various kinds of used packagings to be introduced.

\section{REFERENCES (TRANSLATED AND TRANSLITERATED)}

1. Smittieva revoliutsiia: yak vidvernuty ekolohichnu katastrofu v Ukraini. (n.d.). Retrieved from https://www.epravda.com.ua/columns/2017/07/3/626665/ (in Ukrainian).

2. 30 miliardiv tonn smittia. Ukraina posidaie pershe mistse u sviti za kilkistiu vidkhodiv. (n.d.). Retrieved from http://econews.bei.org.ua/2016/09/30.html (in Ukrainian).

3. Kryvoshei, V. M. (2014). Yakoho koloru buvaie ekonomika? (u vymirakh pakuvalnoi industrii). Upakovka, (5), 14-20 (in Ukrainian).

4. Kalinina, O. S., \& Baitsar, R. I. (2016). Estetychni pokaznyky yakosti pakuvannia. Science Rise, 11(28), 33-43 (in Ukrainian).

5. Trofimov, I. L., Yakovlieva, A. V., Ivanchenko, O. V., \& Vieriahina, L. S. (2016). Analiz potentsialu tverdykh pobutovykh vidkhodiv yak syrovyny dlia vyrobnytstva alternatyvnykh palyv v Ukraini. Enerhetyka: ekonomika, tekhnolohii, ekolohiia, 2(44), 105-111 (in Ukrainian).

6. Safranov, T. A., Shanina, T. P., Hubanova, O. R., \& Prykhodko, V. Iu. (2014). Klasyfikatsiia tverdykh munitsypalnykh vidkhodiv - peredumova formuvannia efektyvnoi systemy povodzhennia z yikh potokamy. Visnyk ODEKU, (18), 32-37 (in Ukrainian).

7. Dovha, T. M. (2011). Klasyfikatsiia pobutovykh vidkhodiv yak peredumova efektyvnosti yikh retsyklinhu v Ukraini. Ekonomichnyi chasopys-XXI, (5-6), 50-53 (in Ukrainian).

8. Nikanorov, S. O. (2014). Zakordonnyi dosvid formuvannia budivel ta sporud smittiepererobnykh kompleksiv. Arkhitekturnyi visnyk KNUBA, (4), 241-249 (in Ukrainian).

9. Zhukovskyi, T. F., Tkachova, O. V., Pshenichnova, O. L., Kartsev, V. H., Kotelevets, M. M., \& Sokolova, O. I. (2016). Vprovadzhennia v Ukraini yevropeiskoho pidkhodu do klasyfikatsii vidkhodiv. Tehnologicheskij audit $i$ rezervy proizvodstva, 4(3), 27-32 (in Ukrainian).

10. Podolchak, I. I., \& Pohrebennyk, V. D. (2017). Klasyfikatsiia upakuvan - skladova chastyna intehrovanoi systemy upravlinnia tverdymy pobutovymy vidkhodamy. Zbirnyk naukovykh prats VI-ho vseukrainskoho zizdu ekolohiv z mizhnarodnoiu uchastiu, 74 (in Ukrainian).

11. Hushtan, T. A. (2016). Problemy utylizatsii vidkhodiv pakuvannia (svitovyi ta vitchyznianyi dosvid). $1 O H O \Sigma, 96-101$ (in Ukrainian).

12. Siryk, T. A. (2011). Vidkhody upakovky ta yikhnia utylizatsiia. Upakovka, (4), 60-61.

13. Slabyi, V. H., \& Kryvoshei, V. M. (2011). Skilky koshtuie utylizuvaty vidkhody upakovky? Upakovka, (6), 49-52 (in Ukrainian).

14. Denysenko, T. M. (2014). Doslidzhennia suchasnykh tekhnolohii probky plastykovykh vyrobiv. Visnyk ChDTU, 1(71), 56-65 (in Ukrainian).

15. Shanina, T. P., Seifullina, I. I., \& Kushnyrova, V. O. (2015). Ekoloho-ekonomichne obgruntuvannia vyboru sposobu povodzhennia z vidkhodamy plastychnykh mas. Visnyk ONU. Khimiia, 20(2(54)), 49-60 (in Ukrainian). 
16. Kirnosova, V. M. (2011). Vymohy ekolohichnoho marketynhu do upakovky tovaru. Visnyk KhNU, 4(6), 57-60 (in Ukrainian).

17. Byorazlahaemaia upakovka s TDPA dobavkamy. (n.d.). Retrieved from: http://www.manfol.ru/products/detail.php?ELEMENT_ID=65/ (in Russian).

18. Mykhalkiv, A. A. (2012). Normatyvno-pravove rehuliuvannia utylizatsii tary. Problemy teorii ta metodolohii bukhhalterskoho obliku, kontroliu $i$ analizu, 2(23), 189-192 (in Ukrainian).

19. Artiushenko, A. Iu., \& Kostenko, O. P. (2012). Problemy pakuvannia tovariv v Ukraini ta shliakhy vyrishennia problem u tsii sferi. Vestnyk $N T U$ «KhPY», 160-165 (in Ukrainian).

Text of the article was accepted by Editorial Team 13.11.2018

\section{І.І. Коваль, В.Д. Погребенник \\ ПІДХОДИ ДО СТВОРЕННЯ ІНТЕГРОВАНОЇ СИСТЕМИ УПРАВЛІННЯ ТВЕРДИМИ ПОБУТОВИМИ ВІДХОДАМИ: КЛАСИФІКАЦІЯ ВІДХОДІВ УПАКОВКИ}

Анотація. У статті розглянуто проблему поводження з відходами упаковки, представлені приклади світових практичних досягнень у цьому напрямку. Вивчено основні особливості відходів упаковки та розроблено їх класифікацію. Запропоновано декілька варіантів заміни упаковки для окремих видів товарів.

Ключові слова: відходи упаковки; класифікація; пакувальні матеріали; вторинна переробка; біоупаковка

\section{Коваль Ірина Ігорівна}

аспірант кафедри екологічної безпеки та природоохоронної діяльності Інституту сталого розвитку ім. В. Чорновола Національного університету «Львівська політехніка»

Адреса робоча: 79057 Україна, м. Львів, вул. Генерала Чупринки, 130

Тел.: 0985756446 e-mail: iralito@i.ua

ORCID ID 0000-0001-8154-4154

\section{Погребенник Володимир Дмитрович}

професор, доктор технічних наук, професор кафедри екологічної безпеки та природоохоронної діяльності Інституту сталого розвитку ім. В. Чорновола Національного університету «Львівська політехніка»

Адреса робоча: 79057 Україна, м. Львів, вул. Генерала Чупринки, 130

Тел.: 0985782530 e-mail: vpohreb@gmail.com

ORCID ID 0000-0002-1491-2356 